\title{
Quality of milk used in informal artisanal production of coalho and butter cheeses
}

\section{Qualidade do leite utilizado na fabricação artesanal informal de queijos de coalho e de manteiga}

\author{
Natália Cristina de Medeiros ${ }^{1 *}$; Maria Rociene Abrantes ${ }^{2}$; \\ Jovilma Maria Soares de Medeiros ${ }^{3}$; Maria Carla da Silva Campêlo ${ }^{3}$; Manoela de \\ Oliveira Rebouças ${ }^{4}$; Maria Gabriela Alves Costa ${ }^{4}$; Jean Berg Alves da Silva ${ }^{2}$
}

\begin{abstract}
Artisanal cheeses such as coalho and butter participate in the socio-cultural identity of people and deserve recognition. Like many artisanal cheeses, it is common to produce coalho and butter cheeses from raw milk. For this reason, it is essential that the raw material from dairies is of good quality to minimize risks to consumers. Thus, this study aimed to evaluate the quality of milk in artisanal cheese factories in Rio Grande do Norte, Brazil. Fifty samples were collected from areas that stand out in dairy production in the state. These samples underwent microbiological and physical-chemical analysis, as well as antibiotic residue and fraud searches. Viable strict and facultative mesophilic bacteria were surveyed, in addition to total and thermotolerant coliforms, Salmonella sp., and Staphylococcus aureus; titratable acidity in Dornic degrees, density, cryoscopy, stability to alizarol, and percentages of protein, lactose, and fat contents were also measured, and tests for residues and recurrent fraud in milk were conducted. In general, all samples exceeded the limit established by law for mesophilic bacteria counting; Salmonella sp. was found in one sample. Given this contamination, the acidity of $76 \%$ of the samples was higher than allowed by the legislation. Regarding fat and protein parameters, $14 \%$ and $10 \%$ of the samples were below the required values by the legislation, respectively. Furthermore, there is suspicion of fraud by adding water in $24 \%$ of samples. Chlorides were found in $16 \%$ and antimicrobial residues in $46 \%$ of samples. Therefore, the quality of the milk used in informal artisanal cheese making in the state of Rio Grande do Norte is poor and may pose a risk to consumers, with the loss of quality of coalho and butter cheeses.
\end{abstract}

Key words: Cheese. Fraud. Raw material. Residues.

\section{Resumo}

Os queijos artesanais, como o de coalho e o de manteiga, participam da identidade sociocultural do povo e merecem valorização. Como muitos queijos artesanais, é comum a fabricação dos queijos de coalho e de manteiga com leite cru. Por isso, é fundamental que a matéria-prima das queijarias apresente boa qualidade, a fim de minimizar riscos aos consumidores. Dessa forma, objetivou-se avaliar a qualidade do leite em queijarias artesanais do Rio Grande do Norte, Brasil. Foram coletadas cinquenta amostras de regiões que se destacam como bacias leiteiras no estado. Elas foram submetidas às análises

\footnotetext{
${ }^{1}$ Discente de Mestrado, Programa de Pós-Graduação em Ciência Animal, Universidade Federal Rural do Semi-Árido, UFERSA, Mossoró, RN, Brasil. E-mail: nataliam2@bol.com.br

2 Profs, Drs., Centro de Ciências Agrárias, UFERSA, Mossoró, RN, Brasil. E-mail: rocienevet3@hotmail.com; jeanberg@ufersa. edu.br

3 Discentes de Doutorado, Programa de Pós-Graduação em CiênciaAnimal,UFERSA, Mossoró, RN, Brasil.E-mail:jovilmasoares@ outlook.com; carlacampelo2@hotmail.com

4 Discentes, Curso de Biotecnologia, UFERSA, Mossoró, RN, Brasil. E-mail: manoelareboucas88@hotmail.com; mgabi_acosta@ hotmail.com

*Author for correspondence
} 
microbiológicas, físicas, químicas, residuais e pesquisa de fraudes. Foram pesquisados microrganismos mesófilos estritos e facultativos viáveis, coliformes totais, termotolerantes, Salmonella sp. e Staphylococcus aureus; acidez titulável em graus Dornic, densidade, índice crioscópico, estabilidade ao alizarol, porcentagens de proteína, lactose e gordura; também foram pesquisados resíduos e fraudes recorrentes em leite. De maneira geral, todas as amostras ultrapassaram o limite estabelecido pela legislação para contagem de microrganismos mesófilos; houve presença de Salmonella sp. em uma amostra. Dada esta contaminação, a acidez de $76 \%$ das amostras estava acima do permitido pela legislação. Quanto aos parâmetros de gordura e proteína, 14\% e 10\% das amostras estavam abaixo dos valores exigidos pela legislação, respectivamente. Além disso, há suspeita de fraude por adição de água em $24 \%$ das amostras. Foram encontrados cloretos em $16 \%$ e resíduos de antimicrobianos em $46 \%$ das amostras. Portanto, a qualidade do leite usado na fabricação informal de queijo artesanal no estado do Rio Grande do Norte não é boa, podendo representar um risco para o consumidor, com o comprometimento da qualidade dos queijos de coalho e de manteiga. Palavras-chave: Fraude. Matériaprima. Queijo. Resíduos.

\section{Introduction}

The production of artisanal cheese, such as coalho and butter cheeses, is considered a strategy for social and economic development, which deserves recognition as a cultural heritage (MENEZES, 2011). Part of the production of artisanal cheeses uses milk without heat treatment; they are produced this way because of their intense and strong flavor when compared to cheeses made from pasteurized milk (YOON et al., 2016). Craft production with raw milk also has support, given the fact that heating the milk can destroy its nutritional benefits and induce some detrimental effects. However, the high nutritional value associated with the neutral $\mathrm{pH}$ and high water activity makes milk an excellent growth medium for different microorganisms, exposing consumers to the risk of foodborne diseases (CLAEYS et al., 2013).

Another risk to consumer health is the residue of veterinary drugs in milk products. Several drugs are used in dairy cattle with prophylactic or curative purposes in an attempt to control mastitis. When the withdrawal time, dosage, and route of administration of these drugs are abused, undesirable residues are formed in food of animal origin (NETTO et al., 2005).

Moreover, the quality and composition of milk can be affected after milking with the addition of foreign or fraudulent substances. The most common frauds of an economic nature in the fluid milk are density reconstitution and the addition of water, neutralizing substances, or whey (FREITAS FILHO et al., 2009). The occurrence of fraud in milk as a raw material and when it is ready for consumption is an economic embezzlement and lowers industrial productivity, and it is associated with consumer health problems (ROBIM et al., 2012). In these terms, knowing the economic importance of the artisanal production of coalho and butter cheeses to Rio Grande do Norte, the tradition of producing these cheeses with raw milk, the consumption of raw cheeses, and the lack of supervision in craft dairies, this study aimed to evaluate the quality of the milk used in informal artisanal cheese factories in this state.

\section{Material and Methods}

Milk samples were obtained from nine informal artisanal cheese factories without inspection. These factories are located in central and western Potiguar, whose production occurs on a small and traditional scale. These factories were selected according to their location in mesoregions with higher production of milk in the state. Moreover, they had to be producing handmade coalho and butter cheeses and agree to participate in this research. Six collections were taken at intervals of 15 days from July to September 2015. We collected one liter of milk from each of the nine dairies every visit. In the first collection, however, only five dairies were available, which resulted in a total of 50 samples: 5 from the first collection and 45 from nine dairies in 
each of the five subsequent collections. The samples were collected in sterile containers directly from the establishment's receiving tanks and then properly refrigerated and sent to the laboratory. There, they were subjected to microbiological and physicalchemical analyses, on the day of collection, tests to evaluate the presence of antimicrobial residues and the occurrence of fraud.

The microbiological analyses that were performed were surveys of viable strict and facultative mesophilic bacteria, total and thermotolerant coliforms, Salmonella sp., and Staphylococcus aureus. For the standard counting test of viable strict and facultative mesophilic microorganisms, total and thermotolerant coliforms, and Salmonella sp., samples were diluted in $225 \mathrm{~mL}$ of $0.1 \%$ peptone water, with successive dilutions in $9 \mathrm{~mL}$ tubes until $10^{-4}$ dilution according to the Normative Instruction 62 (NI 62) from the Ministério da Agricultura, Pecuária e Abastecimento (BRASIL, 2003).

For the total count of mesophilic bacteria, dilutions of each sample were plated in duplicate using the in-depth plating technique, with "plate count agar". Immediately after solidification, the plates were incubated at $36{ }^{\circ} \mathrm{C}$ for 48 hours, and then the counts were held. The counts were performed using a colony counter according to a standard technique in plates containing 25-250 Colony-Forming Units (CFU). The average number of colonies counted in each plate in duplicate multiplied by the corresponding dilution factor provided the number of $\mathrm{CFU} \mathrm{mL}^{-1}$ of mesophilic bacteria in the sample.

For the coliforms, the dilutions were inoculated in $2 \%$ bright green bile lactose broth at $36 \pm 1{ }^{\circ} \mathrm{C}$ for 48 hours to confirm total coliforms. Positive tubes were separated, and fractions were taken and placed in tubes with broth $\mathrm{EC}$ at $45{ }^{\circ} \mathrm{C} \pm 0.2{ }^{\circ} \mathrm{C}$ for 48 hours to search for thermotolerant coliforms. After reading, the Most Probable Number (MPN) of thermotolerant coliforms was found through an MPN table.
In order to search for Salmonella sp., initially the $10^{-1}$ dilution of the samples at $36^{\circ} \mathrm{C}$ was incubated for 20 hours. The dilution of each sample was pipetted in amounts of $0.1 \mathrm{~mL}, 1 \mathrm{~mL}$, and 1 $\mathrm{mL}$ into tubes containing Rappaport Vassiliadis, Selenite, and Tetrationate broths, respectively. These samples were incubated in a water bath at $41{ }^{\circ} \mathrm{C}$ for 24 hours. Then they were plated on agar plates containing Salmonella Differential (Rambach) and Salmonella Shigella Agar (SS) and incubated at $36{ }^{\circ} \mathrm{C}$ for 24 hours. The plates with colony growth had fractions transplanted into tubes containing agar Triple Sugar Iron (TSI) and Lysine Iron Agar (LIA), which were incubated at $36{ }^{\circ} \mathrm{C}$ for 24 hours. Positive tubes were transferred into agar urea and incubated at $36{ }^{\circ} \mathrm{C}$ for 24 hours. Samples that showed color change indicated the presence of urease-positive microorganisms, thus not featuring Salmonella sp. For Staphylococcus aureus, we used $3 \mathrm{M}^{\mathrm{TM}}$ PETRIFILM ${ }^{\mathrm{TM}}$, following the manufacturer's recommendations for inoculation and reading.

The physical-chemical parameters assessed, using a conventional methodology recommended by Adolf Lutz Institute (BRASIL, 2005), were titratable acidity in Dornic degrees; density, using the Incoterm ${ }^{\circledR}$ equipment; cryoscopic index, using the electronic cryoscope Microlak, Entelbra ${ }^{\circledR}$; and stability to alizarol. Protein, lactose, and fat contents were obtained by the ultrasonic milk analyzer Ekomilk Total ${ }^{\circledR}$ according to the manufacturer's recommendations.

The drug residues in milk were surveyed through the Eclipse $50^{\circledR}$ test, which can detect the following antibiotics: Penicillin G, Ampicillin, Amoxicillin, Oxacillin, Cloxacillin, Cephalexin, Cefapirin, Sulfathiazole, Sulfametacin, Sulfanilamide, Oxytetracycline, Tetracycline, Erythromycin, Tylosin, Neomycin, and Streptomycin. Samples were prepared initially by heating to $82{ }^{\circ} \mathrm{C}$ for 5 minutes to inactivate non-specific antibacterial factors in milk. The manufacturer's instructions were followed for inoculation, incubation, and reading. In addition, recurring frauds in milk were 
searched, such as the addition of water and hydrogen peroxide and the presence of alkaline substances, starch, and chlorides for density reconstitution.

Results of density and freezing point were evaluated in order to see whether water was added in the milk. To check for the presence of chlorides, we added $0.5 \mathrm{~mL}$ of $5 \%$ potassium chromate and $4.5 \mathrm{~mL}$ of $0.1 \mathrm{~mol} \mathrm{~L}^{-1}$ silver nitrate in a test tube with $10 \mathrm{~mL}$ of the sample. The test tube was shaken and the color was observed. Chlorides in the upper to normal range are yellow. In order to check if there was starch in the milk, a test tube with 10 $\mathrm{mL}$ of the sample was heated in a water bath at 35 ${ }^{\circ} \mathrm{C}$, and two drops of Lugol were added to it. Blue color indicates the presence of starch. Hydrogen peroxide was investigated by transferring $10 \mathrm{~mL}$ of the sample into test tubes and heating them in a water bath at $35{ }^{\circ} \mathrm{C}$. Then $2 \mathrm{~mL}$ of $1 \%$ guaiacol was added. Salmon color indicates the presence of hydrogen peroxide. As for neutralizing substances, $5 \mathrm{~mL}$ of the milk sample was pipetted into test tubes, and two drops of $2 \%$ rosolic acid was added to it. Pink color indicates the presence of neutralizing substances (BRASIL, 2006). Data were submitted to descriptive statistical analysis.

\section{Results and Discussion}

The milk used as raw material for the production of coalho and butter cheeses in the informal artisanal cheese factories surveyed presented the results shown in Figure 1. Mesophilic microorganisms exceeded the limit of $5.48 \mathrm{CFU} \mathrm{mL} \mathrm{m}^{-1}(\log 10)$ established by law in all samples, reaching scores of $6.398 \mathrm{CFU}$ $\mathrm{mL}^{-1}(\log 10)$. These microorganisms are hygienic indicators, and higher values than the allowed limit suggest that good milking and handling practices were not followed (BRASIL, 2011).

Figure 1. Median, maximum, and minimum values; first and third quartiles for counting Staphylococcus aureus; mesophilic bacteria; and enumeration of total and thermotolerant coliforms in samples of raw milk used for the production of artisanal cheeses (coalho and butter) in informal dairies of Rio Grande do Norte, Brazil, in 2015.

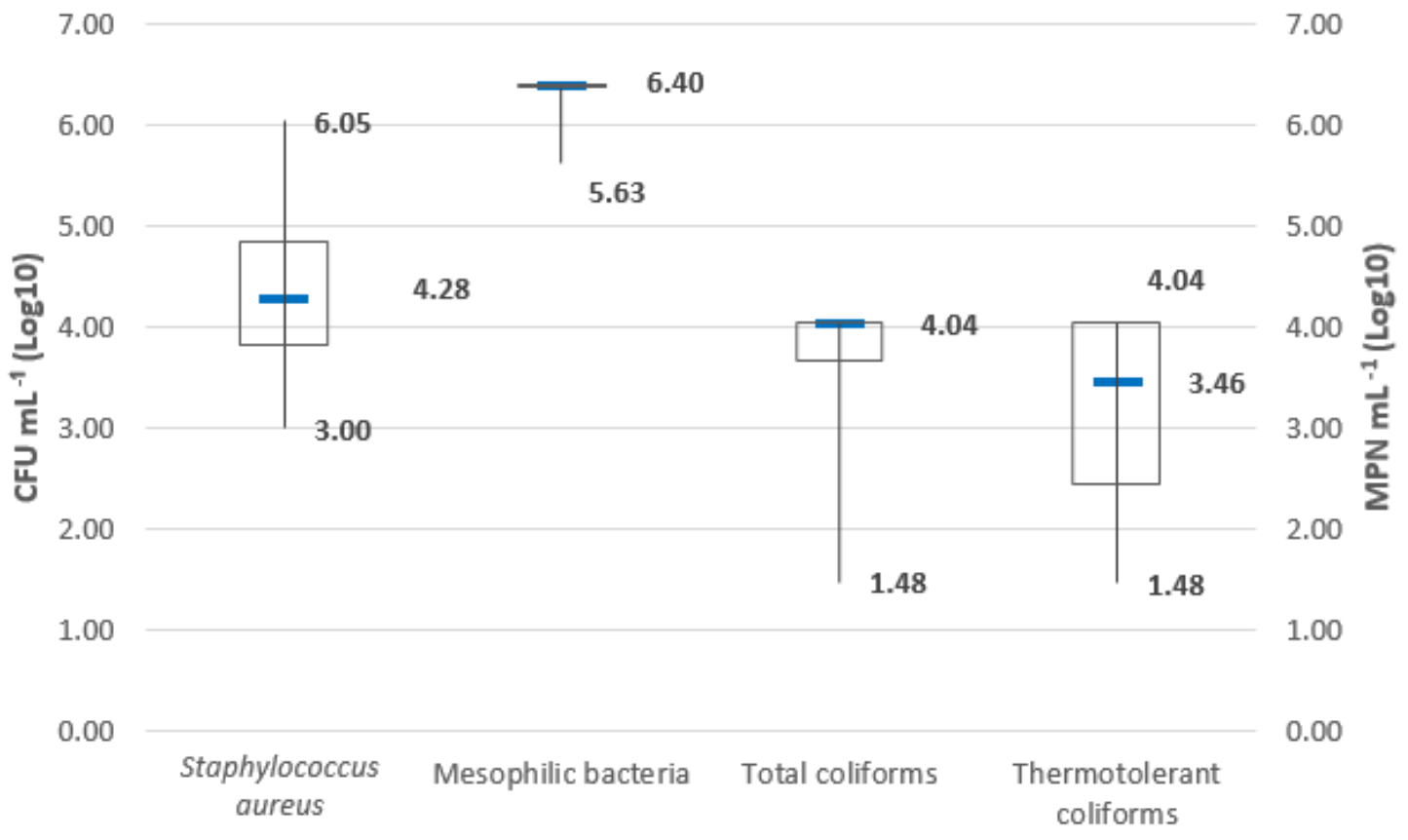


As seen in Figure 1, many samples reached values of $4.04 \mathrm{MPN} \mathrm{mL} \mathrm{mL}^{-1}(\log 10)$ or near it for coliforms at $35{ }^{\circ} \mathrm{C}$. As for coliforms at $45{ }^{\circ} \mathrm{C}$, the distribution was more variable. Although Brazilian law does not advocate values for coliforms at raw milk, their presence should be considered important, as for mesophilic bacteria, which indicate failure to maintain good handling practices, showing a high probability of fecal contamination, directly or indirectly (DANTAS et al., 2013).

Staphylococcus aureus counts, which reached 6.05 CFU mL $\mathrm{m}^{-1}(\log 10)$, detect whether there is a public health problem, as these bacteria can cause food poisoning, producing powerful and harmful toxins that are heat-stable and remain active in food (YOON et al., 2016). Other studies indicate that the lower quality of the milk used as raw material in dairies may be related to contamination by Staphylococcus spp. (BORGES et al., 2008; LAMAITA et al., 2005). Borelli et al. (2006) also confirmed the presence of Staphylococcus spp. in raw milk used in the production of derivatives. Contamination by such microorganisms in raw milk may occur due to mastitis, improper handling, and poor hygiene in general (BELLIO et al., 2016). The practices stated previously have been suggested due to the values of indicator organisms found in this work.

Salmonella sp. is one of the main pathogens involved in food outbreaks worldwide and has been linked to contamination in cheese due to inadequate pasteurization of milk. Bacteria from this genus are found in the intestinal tract of domestic and wild animals, as well as in humans. Because of this, it is associated with non-compliance of good handling practices (SANTANA et al., 2008). Studies show that Salmonella sp. is one of the bacteria that can be transferred from raw milk to humans. The presence of this organism in one sample in this research is worrying, since its ability to cause poisoning is quite relevant, and its presence in a sample makes the product unfit for consumption (BRASIL, 2003).
The microbiological results, therefore, require attention, because the cheese processing steps cannot guarantee the elimination of microorganisms or their toxins. In addition, it is common practice to consume raw coalho and butter cheeses, which increases the risk of foodborne illnesses and brings attention to the need to use quality milk during production (PEIXOTO et al., 2007).

The physical-chemical results are shown in Table 1. It was observed that 21 samples (42\%) were unstable in the presence of alizarol, suggesting acidic milk, which was confirmed by titration. As seen in Table $1,76 \%$ of the samples were above the normal acidity $\left(18^{\circ} \mathrm{D}\right)$. The counts of microorganisms above the law in the milk might explain this acidity, given that in the course of storage and transport to the dairy without cooling, the microorganisms consume lactose and produce lactic acid, increasing the acidity and reducing the $\mathrm{pH}$, and such alterations are reflected in the milk (BRASIL, 2011).

Regarding the compositional parameters of the samples, $14 \%$ had fat values below those recommended by law, and $10 \%$ of samples had

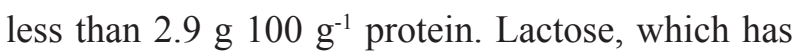
no values defined in the NI 62 (BRASIL, 2011),

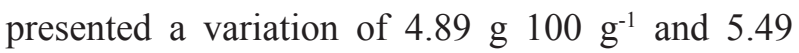
g $100 \mathrm{~g}^{-1}$. Venturoso et al. (2007) compared the compositions of results obtained by the classic methodology and ultrasound, and they found variations in the levels of whole milk fat between

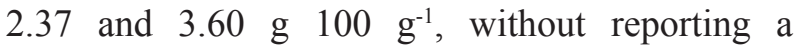
statistically significant difference between the methods of analysis. Santos et al. (2011a) found $20 \%$ of standardized pasteurized milk samples with values below the fat required by legislation, and $60 \%$ of the samples were below the protein values. As the number of samples is below that required by law for fat and protein, these parameters can directly compromise the cheese production yield and interfere with the consistency of the final product (SANTOS et al., 2011a). 
Table 1. Absolute and relative frequencies in samples of raw milk used for the production of artisanal cheeses (coalho and butter) in informal dairies of Rio Grande do Norte, Brazil, in 2015 for analysis of density, cryoscopy, acidity, protein, and fat.

\begin{tabular}{cccccc}
\hline Ocurrence & Density & Cryoscopy & Fat & Protein & Acidity \\
\hline $\begin{array}{c}\text { Samples that obey the } \\
\text { law }\end{array}$ & $36(72 \%)$ & $6(12 \%)$ & $43(86 \%)$ & $45(90 \%)$ & $12(24 \%)$ \\
$\begin{array}{c}\text { Samples that do not } \\
\text { obey the law }\end{array}$ & $14(28 \%)$ & $44(88 \%)$ & $7(14 \%)$ & $5(10 \%)$ & $38(76 \%)$ \\
Total (\%) & $50(100)$ & $50(100)$ & $50(100)$ & $50(100)$ & $50(100)$ \\
NI 62 & 1028 to 1034 & $\begin{array}{c}-0.530^{\circ} \mathrm{H} \text { to } \\
-0.550^{\circ} \mathrm{H}\end{array}$ & Min. 3.0 & Min. 2.9 & $14^{\circ} \mathrm{D}$ to $18^{\circ} \mathrm{D}$ \\
\hline
\end{tabular}

The freezing point and density can be assessed together to examine the possibility of fraud by adding water. In this work, the results were suggestive of this fraud in acidic milk, because the freezing point (88\%) had values below $-0.550^{\circ} \mathrm{H}$, and the density had values below $1028 \mathrm{~g} \mathrm{ml}^{-1}(24 \%)$, in addition to a low percentage of solids. When adding water to acidic milk, the freezing point may be normal or low compared to the law, because the equipment also reads the lactic acid molecules, which are in the solution. The addition of water to milk can reduce the yield of cheeses by dilution, and reduce the solids content, and may worsen the microbiological quality of the milk, since untreated water is usually added. Alongside this, acidic milk can also lead to large losses for the producer, given that acidity is the milk property which has the most influence on the aptitude of milk to coagulation (CALAMARI et al., 2016).

With respect to other fraud research, only the presence of chlorides was a significant finding. There was suspicion of fraud by addition of chlorides in $16 \%$ of the samples. However, we cannot say that the presence of chlorides is indicative of fraud in order to reconstruct the density, since the chloride ion is present in the blood of animals and during inflammatory processes is directed to the lumen of the alveoli of the mammary gland due to increased vascular permeability (ZAFALON et al., 2005). Since the majority of samples were positive for chlorides and antibiotic residues, it is very likely that the presence of chlorides was the result of mastitis in animals, which are treated with drugs; however, the discarding of the milk during the withdrawal time was not performed properly.

Starch, as well as chlorides, is used for reconstructing the density of the milk, which may have been previously altered by the addition of water. On the other hand, hydrogen peroxide is a preservative substance whose addition is intended to preserve the characteristics of the raw materials by inhibiting the growth of microorganisms. The neutralizing substances are used to mask high acidity due to an elevated microorganism count. These neutralizing and conservative substances can represent economic losses and may cause great health risks to consumers, given their effects on the body (SANTOS et al., 2013). In this experiment, no such frauds were found. Mendes et al. (2010) researched frauds in milk commercialized informally in the city of Mossoró/RN, and the only suspected fraud found in that case was the addition of water to milk, which was also detected in our study.

We observed that $46 \%$ of the investigated samples showed antimicrobial residues. The main source of these milk residues is the inadequate management of drugs to control clinical mastitis in dry and lactating cows. It is likely that the animals affected by mastitis received treatment and that the milk was designed for cheese dairies, because they are under less control than inspected dairies. The presence of antibiotic residues in milk can 
have many consequences, such as the selection of resistant bacteria (SANTOS et al., 2011b).

In Rio Grande do Norte, where the samples were collected for this study, the first case was reported of human infection in Brazil by bacteria carrying the mor-1 gene, which confers resistance to the antibiotic class used to treat infections caused by multidrug-resistant bacteria. In South America, E. coli species bearing this gene have been found in food-producing animals since 2012 (FERNANDES et al., 2016). This reinforces the relevance of the data found in this study, in which almost half (46\%) was positive for antimicrobial residues, and serves as a warning to the inspection and health institutions, given the negative consequences of the presence of residues. The high number can be explained by the destination of the low-quality milk. As these samples would be rejected by industries, due to low quality, the milk is intended for informal artisanal cheese factories, which do not make the analysis of the milk, endangering the health of consumers and the quality of the final product.

\section{Conclusion}

The milk used in informal artisanal cheese dairies showed microbial contamination and physical and chemical changes beyond the limits permitted by law. Moreover, the presence of antimicrobial residues reduced the milk quality. There are suspicions of fraud by adding water. Thus, the quality of the milk used in informal artisanal cheese factories in the state of Rio Grande do Norte is poor, which endangers the health of consumers.

\section{Acknowledgements}

We thank the producers and employees of the cheese factories for agreeing to participate in this work and to contribute with this research. We also thank CAPES and CNPq for the support through scholarships and the financing of laboratory equipment and materials.

\section{References}

BELLIO, A.; ASTEGIANO, S.; TRAVERSA, A.; BIANCHI, D. M.; GALLINA, S.; VITALE, N.; ZUCCON, F.; DECASTELLI, L. Behaviour of Listeria monocytogenes and Staphylococcus aureus in sliced, vacuum-packaged raw milk cheese stored at two different temperatures and time periods. International Dairy Journal, Edmonton, v. 57, n. 1, p. 15-19, 2016.

BORELLI, B. M.; FERREIRA, E. G.; LACERDA, I. C. A.; SANTOS, D. A.; CARMO, L. S.; DIAS, R. S.; SILVA, M. C. C.; ROSA, C. A. Enteroxigenic Staphylococcus spp. and other microbial contaminants during production of canastra cheese, Brazil. Brazilian Journal of Microbiology, São Paulo, v. 37, n. 4, p. 545550, 2006.

BORGES, M. F.; NASSU, R. T.; PEREIRA, J. L.; ANDRADE, A. P. C.; KUAYE, A. Y. Perfil de contaminação por Staphylococcus e suas enterotoxinas e monitorização das condições de higiene em uma linha de produção de queijo de coalho. Ciência Rural, Santa Maria, v. 38, n. 5, p. 1431-1438, 2008.

BRASIL. Ministério da Agricultura, Pecuária e Abastecimento. Instrução Normativa 62, de 29 de dezembro de 2011. Regulamento técnico de produção, identidade e qualidade do leite tipo a, de leite cru refrigerado, de leite pasteurizado e o regulamento técnico da coleta de leite cru refrigerado e seu transporte a granel, em conformidade com os anexos desta Instrução Normativa. Diário Oficial [da] União, Brasília, 30 dez. 2011. Seção 1, p. 6.

- Secretaria de Defesa Agropecuária. Instrução Normativa 62, de 26 de agosto de 2003. Oficializa os Métodos Analíticos Oficiais para Análises Microbiológicas para Controle de Produtos de Origem Animal e Água. Diário Oficial [da] União, Brasília, 18 set. 2003. Seção 1, p. 14.

Ministério da Agricultura, Pecuária e Abastecimento. Secretaria de Defesa Agropecuária. Laboratório Nacional de Referência Animal. Instrução Normativa 68, de 12 de dezembro de 2006. Métodos oficiais analíticos físico-químicos para controle de leite e produtos lácteos. Diário Oficial [da] União, Brasília, 14 dez. 2006, Seção 1, p. 8.

Ministério da Saúde. Agência de Vigilância Sanitária, ANVISA. Instituto Adolfo Lutz. Métodos físico-químicos para análise de alimentos. São Paulo: Ministério da Saúde, 2005. p. 821-829.

CALAMARI, L.; GOBBI, L.; BANI, P. Improving the prediction ability of FT-MIR spectroscopy to assess titratable acidity in cow's milk. Food Chemistry, Barking, v. 192, n. 1, p. 477-484, 2016. 
CLAEYS, W. L.; CARDOEN, S.; DAUBE, G.; BLOCK, J. D.; DEWETTINCK, K.; DIERICK, K.; ZUTTER, L. D.; HUYGHEBAERT, A.; IMBERECHTS, H.; THIANGE, P.; VANDENPLAS, Y.; HERMAN, L. Raw or heated cow milk consumption: Review of risks and benefits. Food Control, Reading, v. 31, n. 1, p. 251-262, 2013.

DANTAS, D. S.; ARAÚJO, A. M.; SANTOS, J. O.; SANTOS, R. M. S.; RODRIGUES, O. G. Qualidade microbiológica do queijo de coalho comercializado no município de Patos, Estado da Paraíba. Agropecuária Cientifica no Semiárido, Campina Grande, v. 9, n. 3, p. 110-118, 2013.

FERNANDES, M. R.; MCCULLOCH, J. A.; VIANELLO, M.A.; MOURA, Q.; PÉREZ-CHAPARRO, P. J.; ESPOSITO, F.; SARTORI, L.; DROPA, M.; MATTÉ, M. H.; LIRA, D. P. A.; MAMIZUCA, E. M.; LINCOPAN, N. First report of the globally disseminated incx4 plasmid carrying the mor-1 gene in a ColistinResistant Escherichia coli Sequence Type 101 isolate from a human infection in Brazil. Antimicrobial Agents and Chemotherapy, Washington, v. 60 , n. 10, p. 64156417, 2016.

FREITAS FILHO, J. R.; SOUZA FILHO, J. S.; GONÇALVES, T. M.; SOUZA, J. J. F.; SILVA, A. H. I.; OLIVEIRA, H. B.; BEZERRA, J. D. C. Caracterização físico-química e microbiológica do leite 'in natura' comercializado informalmente no município de Garanhuns - PE. Revista Brasileira de Tecnologia Agroindustrial, Ponta Grossa, v. 3, n. 2, p. 38-46, 2009.

LAMAITA, H. C.; CERQUEIRA, M. M. O. P.; CARMO, L. S.; SANTOS, D. A.; PENNA, C. F. A. M.; SOUZA, M. E. Contagem de Staphylococcus sp. e detecção de enterotoxinas estafilocócicas e toxina da síndrome do choque tóxico em amostras de leite cru refrigerado. Arquivo Brasileiro de Medicina Veterinária e Zootecnia, Belo Horizonte, v. 57, n. 5, p. 702-709, 2005.

MENDES, C. G.; SAKAMOTO, S. M.; SILVA, J. B. A.; JÁCOME, C. G. M.; LEITE, A. I. Análises físico-químicas e pesquisa de fraude no leite informal comercializado no município de Mossoró, RN. Ciência Animal Brasileira, Goiânia, v. 11, n. 2, p. 349-356, 2010.

MENEZES, S. S. M. Queijo de coalho: tradição cultural e estratégia de reprodução social na região nordeste. Revista de Geografia UFPE, Recife, v. 28, n. 1, p. 40-56, 2011.

NETTO, D. P.; LOPES, M. O.; OLIVEIRA, M. C. S.; NUNES, M. P.; MACHINSKI JÚNIOR, M.; BOSQUIROLI, S. L; BENATTO, A; BENINI, A.; BOMBARDELLI, A. L. C.; VEDOVELLO FILHO, D.; MACHADO, E.; BELMONTE, I. L.; ALBERTON, M.; PEDROSO, P. P.; SCUCATO, E. S. Levantamento dos principais fármacos utilizados no rebanho leiteiro do
Estado do Paraná. Acta Scientiarum Animal Sciences, Maringá, v. 27, n. 1, p. 145-151, 2005.

PEIXOTO, A. M. S.; PRAÇA, E. F.; GÓIS, V. A. A potencialidade microbiológica de coagulação do coalho líquido artesanal. Revista Verde de Agroecologia e Desenvolvimento Sustentável, Pombal, v. 2, n. 2, p. 5264, 2007.

ROBIM, M. S.; CORTEZ, M. A. S.; SILVA, A. C. O.; FILHO, R. A. T.; GEMAL, N. H.; NOGUEIRA, E. B. Pesquisa de fraude no leite UAT integral comercializado no estado do Rio de Janeiro e comparação entre os métodos de análises físico-químicas oficiais e o método de ultrassom. Instituto de Laticínios Cândido Tostes, Juiz de Fora, v. 67, n. 389, p. 43-50, 2012.

SANTANA, R. F.; SANTOS, D. M.; MARTINEZ, A. C. C.; LIMA, Á. S. Qualidade microbiológica de queijo-coalho comercializado em Aracaju, SE. Arquivo Brasileiro de Medicina Veterinária e Zootecnia, Belo Horizonte, v. 60, n. 6, p. 1517-1522, 2008.

SANTOS, A. F. S.; DUARTE, K. M. R.; POZZI, C. R. Detecção de resíduos de antimicrobianos no leite. UNOPAR Científica Ciências Biológicas e da Saúde, Londrina, v. 13, n. 3, p. 205-212, 2011 b.

SANTOS, N. A. F.; LACERDA, L. M.; RIBEIRO, A. C.; LIMA, M. F. V.; GALVÃO, N. R.; VIEIRA, M. M.; SILVA, M. I. S.; TENÓRIO, T. G. S. Avaliação da composição e qualidade físico-química do leite pasteurizado padronizado comercializado na cidade de São Luís, MA. Arquivos do Instituto Biológico, São Paulo, v. 78, n. 1, p. 109-113, 2011 a.

SANTOS,P.M.;PEREIRA-FILHO,E.R.; RODRIGUEZSAONA, L. E. Rapid detection and quantification of milk adulteration using infrared microspectroscopy and chemometrics analysis. Food Chemistry, Barking, v. 138, n. 1, p. 19-24, 2013.

VENTUROSO, R. C.; ALMEIDA, K. E.; RODRIGUES, A. M.; DAMIN, M. R.; OLIVEIRA, M. N. Determinação da composição físico-química de produtos lácteos: estudo exploratório de comparação dos resultados obtidos por metodologia oficial e por ultra-som. Revista Brasileira de Ciências Farmacêuticas, São Paulo, v. 43, n. 4, p. 607-613, 2007.

YOON, Y.; LEE, S.; CHOI, K. H. Microbial benefits and risks of raw milk cheese. Food Control, Reading, v. 63, n. 1, p. 201-215, 2016.

ZAFALON, L. F.; NADER FILHO, A.; OLIVEIRA, J. V.; RESENDE, F. D. Comportamento da condutividade e do conteúdo de cloretos do leite como métodos auxiliares de diagnóstico na mastite subclínica bovina. Pesquisa Veterinária Brasileira, Rio de Janeiro, v. 25, n. 3, p. 159163, 2005. 